\title{
Violence, Terrorism, and Identity Politics in Afghanistan: The Securitisation of Higher Education
}

\author{
Christian Kaunert ${ }^{1, *(D)}$ and Arif Sahar ${ }^{2}$ (D) \\ 1 International Centre for Policing and Security, University of South Wales, Pontypridd CF37 4BD, UK \\ 2 Centre of Excellence in Terrorism, Resilience, Intelligence and Organised Crime Research [CENTRIC], \\ Sheffield Hallam University, Sheffield S1 1WB, UK; a.sahar@shu.ac.uk \\ * Correspondence: christian.kaunert@southwales.ac.uk
}

Citation: Kaunert, Christian, and Arif Sahar. 2021. Violence, Terrorism, and Identity Politics in Afghanistan: The Securitisation of Higher Education. Social Sciences 10: 150. https://doi.org/10.3390/socsci10050150

Academic Editor: Andreas Pickel

Received: 5 March 2021

Accepted: 16 April 2021

Published: 25 April 2021

Publisher's Note: MDPI stays neutral with regard to jurisdictional claims in published maps and institutional affiliations.

Copyright: (c) 2021 by the authors. Licensee MDPI, Basel, Switzerland. This article is an open access article distributed under the terms and conditions of the Creative Commons Attribution (CC BY) license (https:// creativecommons.org/licenses/by/ $4.0 /)$.
Abstract: This article investigates the securitisation of the higher education sector in Afghanistan by examining 'hidden' non-discursive practices as opposed to overt discursive threat construction. Non-discursive practices are framed by the habitus inherited from different social fields, whereas in Afghanistan, securitising actors converge from different habitus (e.g., institutions, professions, backgrounds) to bar the 'other' ethnic or social groups from resources and spaces which could empower these groups to become a pertinent threat, a fear, and a danger to the monopoly of the state elites over the state power and resources. The most prominent securitisation practices emerging from the data include mainly (1) the obstruction of the formation of critical ideas and politics; (2) the obstruction of economic opportunities; and (3) the obstruction of social justice. This article deploys a case study methodology and uses the Kabul University as its subject of investigation.

Keywords: Afghanistan; securitisation; violence; higher education; identity politics; statebuilding

\section{Introduction}

The Afghan state has been juggling an amalgamation of competing forces, including the power of Islam, tribal politics, ethnic grievances, socioeconomic underdevelopment, and multiple foreign invasions. The Afghan state has remained besieged with persistent challenges and threats such as state fragility, deteriorating security, and growing ethnopolitical tensions, exacerbated particularly by the civil wars (1978-2001) and the ongoing insurgency (2001-present). The civil wars destabilised the central political system and left it open to contestations and negotiations between different ethno-regional and political factions. The civil wars were not only articulated and fought primarily on ethno-regional grounds but also sharpened the identity politics that forms popular perceptions, perspectives, and relationships with the state in the post-2001 context (Sahar 2014; Simonsen 2004). In the post-2001 era, amid significant progress in education and civil society and media, state stability and national integrity are threatened by the growing incursion of a variety of radical (Pherali and Sahar 2018) and ethno-nationalist (Sahar and Sahar 2015) actors into state structures to influence the state policies and practices appertaining to certain areas, including educational settings and processes. The volatile mix of fear (return to war or a challenge to state authority) and feasibility (the state's ability to curb ethnic aspirations or the ethnic aspirants challenging the state to claim their share) places the Afghan state in a condition of persistent negotiations, contestations, and compromise amongst varied ethno-regional groups or pacts. This condition generates an element of fear within the state and can encourage the state to safeguard its security at the expense of securitising social formations and their intersubjectivities, including discourses and practices that the state perceives a security threat to its authority or monopoly over power and resources.

This article uses securitisation theory as its analysis framework and investigates how the higher education sector in Afghanistan is securitised by the state elites through utilising 
their agency (e.g., power and positions) to restrict the socioeconomic and political aspirations of certain ethnic and social groups. In Afghanistan, state elites are a small group or network of powerful individuals who possess disproportionate political power/influence, privilege, or wealth and have historically controlled the state, showing a tremendous resistance to the restructuring of power structures or transformations that could have undermined their position. The article examines the securitisation of the access to higher education by more ethnic and social groups, resulting in the empowerment of these groups, and are embodied mainly in the political and economic competitions, contestations, and participation. This increasing influence of more ethnic groups over political or socioeconomic developments is perceived by the elites as a threat to the existence of a centralised state that enables these elites to preserve their monopoly over the state power and resources. The article also analyses how higher education, by empowering the traditionally marginalised groups, is perceived by the state elites to facilitate the decentralisation of the state through network building and political organisations, academic training, and socialisation of its subjects into ideals of social justice in the 'securitized' conflict environment of Afghanistan. The article contributes to the existing literature in multiple ways. First, it adds to the nascent literature on the securitisation of education in securitised environments and destabilises the orthodox narrative often advanced by the national states and international development partners that inclusive education serves societies equitably. Second, the article tests the suitability of the theoretical framework presented by the securitisation theory outside the West. The article illustrates the ways in which a presumption that Western understandings of the state and society are universal informs the normative concepts underlying the framework-and undermines the framework to capture the specific local sociopolitical context. The most popular concepts in the sub-discipline of International Security and the debates thereof are deeply rooted in Western (especially Europe and North America) historical and political epistemology. The idea of securitisation was developed and applied, consciously or unconsciously, aiming at the established political contexts and democracies of Europe. The Western orientation and focus of securitisation theory is criticised for its discriminatory and racist foundations 'structured not only by Eurocentrism but also by civilizationism, methodological whiteness, and antiblack racism (Howell and Richter-Montpetit 2020). It is further criticised that 'classic securitization theory' advances a conceptualisation of 'normal politics' as reasoned, civilised dialogue, and securitisation as a potential regression into a racially coded uncivilized 'state of nature' (Howell and Richter-Montpetit 2020, p. 3). In order to enhance the securitisation theory's adaptability to wider contexts, it is suggested the concept of securitisation ought to be recuperated from these racist foundations (Howell and Richter-Montpetit 2020, p. 3). Thus, this article aims to decentralise the securitisation of higher education, which has been almost exclusively focussed on Western contexts, notably in relation to counter-terrorism strategies. Third, the article, through the case of the securitisation of the higher education sector in Afghanistan, highlights that the centrality of the speech-act for securitisation results in the theory developing a Westernised analysis of a particular situation. Fourth, by exploring the securitisation of education from a non-Western context where most studies in this area have focussed on educational context in Western countries, this article offers a distinct national focus-on Afghanistan. The article is divided into three main sections. The first section discusses securitisation of/and education and/or higher education-analysing and critiquing the securitisation theory for its insufficient focus on practices of securitisation and (higher) education. The second section offers an analysis of the securitisation of higher education and its implications for societal cohesion or fragmentation (e.g., education has historically often been an instrument of nationalist and capitalist groups to forward their interests) in the conflict-affected context of post-2001 Afghanistan. Section 3 discusses the article's empirical findings on the securitisation practices and instruments within higher education in Afghanistan. The article concludes that in the 'securitised' environments, such as Afghanistan, higher education plays a very significantly role, perhaps more than anticipated, to socialise individuals into ideals of social justice, to promote economic and 
political participation for all groups, and societal cohesion. These values-based ideas would ultimately undermine the underlying factors of societal tensions, which provide the core premises of the securitisation behaviours and practices of the state elites.

\section{Securitisation of Education/Higher Education: A Conceptual Framework}

The concept of 'securitization', as an analytical framework, lies at the heart of securitisation theory, originally developed by the Copenhagen School in 1995 (Wæever 1995).The securitisation theory states that an issue is transformed into a security issue (i.e., securitised) after a securitising actor presents it as an existential threat and this 'securitizing move' is accepted by the 'audience' (Léonard and Kaunert 2010, 2019; Buzan et al. 1998). Accordingly, 'securitization' implies 'the staging of existential issues in politics to lift them above politics. In security discourse, an issue is dramatized and presented as an issue of supreme priority; thus, by labelling it as security, an agent claims a need for and a right to treat it by extraordinary means' (Buzan et al. 1998). The securitisation of an issue takes a processional and sequential order and commences whenever elite actors inject 'low politics' public policy issues into the domain of 'high politics', by adopting the rhetoric of existential threat (Wæver 1995, p. 46; Messina 2014; Balzacq 2005).In this context, Lazaridis (2011), assessing the securitisation of immigration states that 'securitization is essentially a 'top down' process, in which various political, societal and security elites present migration as [a] threat to fundamental values of societies and states.' The elites, to generate legitimacy for their 'securitizing moves', seek to transfer the issue in question out of the realms of conventional politics and into the domain of emergency politics, where it can be expeditiously resolved (Hampshire and Saggar 2006). Essentially, 'the securitization is the antithesis of the methods and procedures by which elites normally seek the public's support for their preferred policies' (Messina 2014).

However, the Copenhagen School has been criticised by the sociological approach advanced by the Paris School for its narrow focus on speech act and the presumed automatic reaction associated with speaking the term security, a sort of 'social magic' (Balzacq et al. 2010; Bigo 2001).The Paris School scholarship views securitisation as a multilayered process and outlines how it occurs over time as a context-specific process, informed and conducted by different practices, both discursive and non-discursive, such as the media. This scholarship describes the different securitisation practices as instrumental in the securitisation of issues surrounding identity and migration (Léonard 2010; Bingo 2002; Balzacq et al. 2010; McSweeney 1996), energy and the environment (Ciută 2010; Corry 2012), and religion (Karyotis and Patrikios 2010). A particular example that has recently attracted attention is FRONTEX. It is an agency established by European Union Member States in 2004, aiming at '[facilitating] the application of existing and future Community measures relating to the management of external borders by ensuring the coordination of Member States' actions in the implementation of those measures' (recital 4 of Council Regulation (EC) No. 2007/2004). FRONTEX is highlighted to have played a pivotal part in the securitisation of border security and migration into the EU through numerous practices such as the coordination of operational cooperation between Member States regarding the management of external borders (Léonard 2010).

However, it remains nascent whether these practices are always overt, like in the case of the cited literature or in cases of conflict environments. It also remains pretty much unclear whether these practices can be implicit (non-discursive), thus remaining hidden, in order not to provide a too controversial element of what is already a conflictual environment. However, the Paris School has suggested that securitisation, by breaking away from the exceptional, breaking point of the speech act, can take hold through the everyday practices of actors involved in policymaking and implementation (Balzacq et al. 2010; Bigo 2001). These non-discursive practices, meanwhile, may not necessarily lead to spectacular outcomes but are effective in informing the process of constructing an issue as a security challenge. This non-discursive practice is completed by collecting information, categorising people, associating them with more or less dangerous categories, and evoking 
expert knowledge to do so (Trombetta 2014). Additionally, more scholarship has recently argued that an issue (e.g., migration) can be securitised through non-discursive social practices (Léonard 2010), which can be performed by the everyday practices of societal agents. A sociological approach, which is claimed to be stronger than a purely linguistic approach to securitisation for its capability to combine discursive and non-discursive formations, including know-how, gestures, and technology, suggests taking both discursive and non-discursive practices seriously by focussing on patterns of security practices (Balzacq et al. 2010). Social interactions are not only rule-governed (as in the speech act approach) (Balzacq et al. 2010), but also as the sociological view emphasises, rule-generating (Pleasants 1999. )Non-discursive practices, therefore, are not substitutes for discursive practices, but both are equally important for the analyst as they feature different 'logics' but can produce the same effects (Balzacq et al. 2010).

Additionally, securitisation does not necessarily need to happen through rational design, wherein the securitisation act follows a predetermined agenda as 'social action is not necessarily preceded by a premeditated design ... a practice can be oriented toward a goal without being consciously informed by it' (Vincint 2008). Essentially, securitisation contains within it some practices such as non-discursive practices 'which instantiate intersubjective understandings and which are framed by the habitus inherited from different social fields' (Balzacq et al. 2010). In Afghanistan-discussed at length in the empirical section-the securitising agents converge from different habitus (e.g., institutions, professions, backgrounds) to bar the 'other' groups from resources and spaces that could empower these groups to become a pertinent threat, a fear, and a danger to the monopoly of the state elites over the state power and resources. These practices, albeit non-discursive, create conditions — which can be physical, technical, material, and historical (Bigo 2006) - that may breed the essential threat logic for securitisation moves.

Regarding the contextual relevance and context-specificity of securitisation theory, while securitisation theory has traditionally been geared towards Western contexts and practices for most its life, some recent scholarship has sought to apply it to non-Western contexts (Greenwood 2013; Wilkinson 2007; Ezeokafor and Kaunert 2018). Greenwood (2013) has applied securitisation theory to the case of Egypt in the light of the Arab Spring and the broader Middle Eastern context, when the entire Egyptian security sector was implicated and drawn into dealing with a range of security challenges, including social unrest, religious extremism, and economic disruption. The theory is utilised to chart how the Egyptian revolution could be understood through securitisation theory. Claire Wilkinson (2007) has applied securitisation theory to the case of the overthrow of the government in Kyrgyzstan in March 2005. She argues that theoretical shortcomings result in a simplified and Westernised description of the situation that does not take into account the specific local sociopolitical context. She further argues that if the Copenhagen School's theoretical framework is to be considered suitable for universal application, future theoretical developments must explicitly address the theoretical shortcomings and empirical limitations of the framework. Ezeokafor and Kaunert (2018) have attempted to reconceptualise the securitisation-neopatrimonialism nexus in Africa to develop new insights into non-Western political contexts. The framework is used to analyse the securitisation processes among the political elites in a neopatrimonial statehood, stretching the conceptualisation of securitisation into African statehood, characterised by a blurred line between the leader and the state. Similarly, Fisher and Anderson (2015) used securitisation theory to study the securitisation of development in Africa. The authors, drawing on the critiques of the theory in non-Western contexts, argue that 'securitization' has had an unwelcome and negative impact on key development areas such as social development, human rights, and governance reform owing to the theory's failure to account for the distinct political and social dynamics that are at play in local settings.

Relatedly and of more relevance to this article is a recent strand of literature that advocates for the involvement of 'vernacular' approach in security studies, emphasising the significance of a 'bottom-up' approach that foregrounds 'ordinary' people and their 
daily existence. Nils Bubandt (2005, p. 291), studying the diverse ways in which Indonesian communities responded to national security discourse, argues for a reconceptualisation of security as a concept that is 'conceptualized and politically practiced differently in different places and at different times.' Bubandt further argues that security is 'neither unchanging nor conceptually homogeneous'; thus, understandings of a 'local' or 'lower' level of analysis will provide a new dimension to the working of (top-down) security politics (Bubandt 2005, p. 291). Bubandt goes on stating that if security as a concept is to meet the complex situations, politics, and practices, it must include a greater 'comparative analysis of the ontological grounding and political management of socially specific fears and uncertainties' (Bubandt 2005, p. 291). Bubandt concludes that securitisation theory must be reconceptualised to include vernacular securities in order to be more situated, contextspecific, and capable of accounting for 'the idioms of uncertainty, order and fear as well as the forms of social control associated with particular discourses on security', whether these discourses are 'global', 'national', or 'local' (Bubandt 2005, p. 291). Bubandt's work has sparked significant interest in contemporary research. Croft and Vaughan-Williams (2016) emphasise the importance of the 'security speak' facilitated by vernacular approach of individuals traditionally marginalised in studies informed by global approach to security or politics. A vernacular securities approach, therefore, provides better understandings of 'how citizens construct and describe experiences of security and insecurity in their own vocabularies, cultural repertoires of knowledge and categories of understanding' (Croft and Vaughan-Williams 2016, p. 11). Additionally, the ways in which ordinary people themselves define, experience, and try to ensure their own security must be foregrounded (Luckham 2017); thus, 'security in the vernacular' emphasises that those who are vulnerable and insecure are not just social categories but people, groups, and communities who perceive, cope with, and respond to violence in ways that differ, sometimes radically, not only from the dominant state security narratives, but sometimes also from universal conceptions of human and citizen security (Luckham 2017).

Reflecting on the origin, interlocutors, and contributions of vernacular securities approach, Lee Jarvis states that vernacular approach's 'conceptual emptiness allows for genuinely inductive research into public experiences, understandings, anxieties, and fears ... it offers engagement with a potentially far richer tapestry of everyday (in)securities by refusing to prioritise particular populations by virtue of their identity or sociopolitical position ... it avoids the universalism inherent within related, yet more explicitly cosmopolitan, approaches to security (Jarvis 2019, p. 107). In the case of Afghanistan, the vernacular securities offer insights into the complex contexts-informed by the legacies and fear of previous civil wars (1978-2001) — and social and ethnic marginalisation and ways in which securitisation moves are carried out in more subtle forms of exclusion, including undermining aspirations (e.g., ethno-regional or social groups' desire of political or economic participation) that are perceived of by the securitising actors (e.g., state elites) a security threat to the heavily centralised state structures. Additionally, in the context of Afghanistan, the vernacular approach may provide better understandings of the localised construction of security threats and subjects by offering clearer insights into how a confluence of different actors from different state institutions is formed and informed by a shared interest, a centralised state. This conceptual analysis of the securitisation theory, practices, and approaches takes us to the next section that explores how education is securitised in different contexts.

\section{Securitisation of Education/Higher Education}

Securitisation of education has seen rapid growth in recent years. Some scholars have studied the securitisation of climate change through school textbooks in Germany, arguing that textbooks are used as facilitating conditions for securitisation processes. These scholars suggest that school textbooks can function as an important medium of reflecting consolidated discursive realms and can be instrumental in transmitting them to future generations (Ide et al. 2019). Other research into education in conflict-affected 
context of Cyprus, tracing genealogies of affects and emotions related to memory, trauma and ethnic conflict provides an important point of orientation on how Greek-Cypriot schools have historically constituted affective discourses and practices on security, ethnic identity, and conflict/peace (Zembylas 2020). This research also states that students and educators are emotionally engaged in everyday securitised discourses and practices that construct the 'enemy-ethnic other' (Turks and Turkish-Cypriots) as 'fearful' and 'dangerous' (Zembylas 2020). These discourses and practices are argued to rely on the manipulation of certain affects and emotions-e.g., the Turkish military invasion of Cyprus in 1974 and the fear that the Turks will capture the rest of Cyprus- that happens at the micropolitical level within and beyond schools to reproduce constructions of the ethnic other as dangerous, volatile, and threatening (Zembylas 2020). Through these discourses and practices, students and educators are actively and emotionally involved with issues that become deeply securitised in their everyday lives (Zembylas 2020).

Some research has explored the processes and practices of advancing religious education in a number of EU states, arguing that democratic states, in response to increased cultural and religious diversity, seek to encourage tolerance (e.g., through promoting human rights), and therefore choose to develop policies concerning 'religious education' or 'teaching about religions and beliefs' to support it (Gearon 2012; Jackson 2015). The approach of these states to the development and implementation of religious education leads to the 'politicisation' of religious education and their interest in social cohesion goes, therefore, beyond the idea of promoting pluralism, extending into the murky field of security. The religious education classroom wherein issues of social cohesion and more contentious issues of citizenship are taught, becomes highly emotively, 'the counter terrorist classroom (Gearon 2012).' Additionally, scholarship has increasingly paid attention to 'the overt and covert linkages between security and education' (Durodie 2016), amid growing concerns over radicalisation and violent extremism, especially among youth (Zembylas 2020). For instance, the Prevent programme across the EU is argued to establish and perpetuate securitised discourses that pathologise certain individuals (often Muslims) as 'vulnerable' and 'problem' subjects who are inclined to be drawn to radicalism and extremism (Zembylas 2020). Securitising educational programmes, therefore, end up creating a surveillance regime that seeks to co-opt educators, administrators, and students as agents of the state against 'problem' individuals (Zembylas 2020; Arshad-Ayaz and Naseem 2017). The increasing securitisation of education has led to a growing engagement of security and intelligence agency engagement with schools and universities and, thus, the research on the actualities of this engagement has witnessed a rapid expansion.

The scholarship on the impacts of the securitisation and politicisation of education suggests that the impact of education can be minimal, especially compared to other aspects of socialisation. A study on the impacts of the securitisation of climate change through school textbooks in Germany suggests that 'young people who read school textbooks using an alarmist logic are indeed more likely to conceive climate change as an urgent threat necessitating extraordinary measures, and are thus more likely to accept the securitization of climate change (Ide et al. 2019).' Another study on students' cultural comprehension of textbook narratives on the Israeli-Arab conflict found that students 'culturally comprehended' the textbook, or, in other words, that the nature of the students' recollection was strongly affected by the social memory of the group within which they lived (Porat 2004). There is ample evidence on the persistence and affection of an irreducible relationship between text and agent- the relation between the cultural tool of the textbook and the cultural agent's reading of it (Porat 2004). Similarly, research into the link between curriculum and national identity in Pakistan suggests that the complex nexus of education, religion, and national identity tends to construct 'essentialist' collective identities-a single identity as a naturalised defining feature of the collective self (Durrani and Dunne 2010). The study further finds that the Pakistani state, in order to promote national unity across the diverse ethnic groups comprising Pakistan, uses the national curriculum to demarcate the key boundary between the Muslim Pakistani 'self' and the antagonist non-Muslim 'other' 
(Durrani and Dunne 2010). This practice, according to the study, 'creates social polarization and the normalization of militaristic and violent identities, with serious implications for social cohesion, tolerance for internal and external diversity, and gender relations (Durrani and Dunne 2010).' With this broader discussion of how education is securitised under different circumstances for numerous purposes and how learners absorb its impacts, the next section provides a more specific analysis of the ways in and through which education or higher education has been securitised within the historical and contemporary securitised environment of Afghanistan.

\section{Securitisation of Higher Education in Afghanistan}

Afghanistan's population has been estimated 32 million people (Trading Economics). Out of a large number of ethnic groups, four represent the majority groups, which have, at times, indulged in violent conflicts over power and state resources. The ethnic composition of the Afghan population is unknown. However, according to some estimates, the Pashtuns constitute 38\%, Tajiks 25\%, Hazaras 19\%, and Uzbeks and Turkmen 10\% of the population, respectively (Carol 2005). Afghanistan is a multi-ethnic state, where ethnic groups are marked with indelible, rigid, and clear-cut boundaries and are split along peculiar characteristics - rendering them 'solid cultural units which are divided by obvious boundaries and have engaged in conflict for hundreds of years' (Schetter 2004). This cultural diversity, in the absence of an inclusive national identity and widespread discriminations against certain ethnic and social groups, has yielded conflicting aspirations and perspectives. Throughout history, the Afghan elites have failed to forge a political entity that mirrors this sociocultural and ethno-political diversity. It has been argued that

'Afghan ethnic groups have never viewed themselves as fixed nationalities with an overriding commonality and history that would require political unity or a nation state. Instead, ethnicity in Afghanistan is essentially pre-nationalist, with ethnic groups holding similar economic and political interests but no common ideology or separatist aspirations'. (Barfield 2011, p. 56)

Since the creation of modern Afghanistan in 1747, the Pashtuns, as the largest ethnic group, have ruled the country except for a short interruption (1992-1996), when, following the communist collapse, a Tajik leader served as the president. In the post-2001 contexts, whilst the Pashtuns have been in the saddle, other ethnic groups have been playing critical part in the democratisation processes, such as in elections. These ethnic groups have also seriously challenged and undermined the Pashtun elites' monopoly of the state and its institutions (Sahar 2014). This development has seriously disrupted the power relations between these competing ethnic groups, and, therefore, leads the Pashtun elites to restrict the aspirations of other ethnic groups. In these struggles over power, higher education can be a security threat to a centralised state that is highly likely to remain in the grip of the Pashtun elites for a foreseeable future, and is portrayed as such.

In the post-2001 context, ethnicity has re-emerged as an underlying force in alliance making, elections, and reconstruction processes (Sahar and Sahar 2015; Simonsen 2004). Although there are no explicit speech acts or practices appertaining to the securitisation of the higher education sector in Afghanistan, this securitisation move takes place through 'non-discursive' means in terms of discriminating against certain ethnic groups by ethnopolitical elites who control or influence the state. However, it is important to note that presenting this case as an example of 'non-discursive' securitisation can be problematic that it becomes difficult to make a convincing analysis that that a securitising move ever really took place. This leads to some critical questions: If inclusive education was not made a security issue through overt speech acts, then how was it? How do we know that the issue was securitised and that the exclusion was not based on other grounds such as racism or simple economic interest? Two analytical routes would have provided some mitigating measures to redress these challenges. One way to do this is by returning to securitisation theory's roots and to focus on the breaking of rules. It would have been an examination of whether the Afghani Ministry of Higher Education nominally has rules 
aimed at inclusive access to education, but those rules are broken in the name of preserving some referent object. Another route was to rely on the themes that emerged from the discussions with informants, wherein they describe the higher education system through securitised language. Since the majority of informants described the higher education system through securitised language with a clear understanding of the implications of their language, and to preserve the authenticity of the subject, we adopted the second route.

In the process of securitisation moves, the elites try to bar other ethnic and social groups from entering political, economic, and social spheres (where different actors interact and accumulate new or protect exiting power and wealth) as this development would threaten the preservation of a centralised state that perpetuates elites' monopoly on power. These processes and institutions, including higher education, would be perceived as central threat factors for the elites by empowering the marginalised groups to challenge and, at times, even strive by undermining the monopoly of state power and resources by the elites. In non-Western contexts, Ezeokafor and Kaunert (2018) have shown that political elites can monopolise both the tangible and intangible resources of the state to maintain their hold on power and define the security pattern of their individual countries: who frames the threats and to what extent does the specific character of the state play a role in securitisation process outside the West? Ezeokafor and Kaunert (2018) have demonstrated that, in the African context, the influence of neopatrimonialism is significant on the whole workings of the state and, thus, securitisation processes. Here, the nature of the patron-client system in a country is necessary to understand the behaviour and activities of members of the political class and warlords. Patrimonialism, arguably, is a system of personal leadership on the basis of loyalties that do not require any belief in the ruler's unique personal qualification but are inextricably linked to material incentives and rewards (ibid.). This is an adaptation of Max Weber's types of authority based on legal authority, namely traditional authority and charismatic authority. The patrimonial system of authority can accordingly be said to draw from a combination of traditional and charismatic authority. The chief gains legitimacy from his being a custodian of traditional ways of the people and a certain heroism he might have displayed in wars against the people's enemies. Instead of bureaucratic staff, his staff members are drawn from his household members, slaves, personal retainers, and also from his cronies, who are beholden to him in a favour-for-support reciprocity.

It is important to note that patrimonialism is not restricted to Africa; it is part and parcel of the workings of all traditional societies-Africa, America, Asia, and Europe. It is also to be found in Afghanistan. The most significant feature of the neopatrimonial system of authority is that the Weberian rational-legal bureaucracy is inconsequential. Even though there are institutions and bureaucracies, they are personal tools in the hands of the rulers to wield authority over the people. It is neopatrimonial because it is a medley of tradition and modernity in which the elites control the whole state apparatus, including the security sector. The impetus for the intricacies and dynamics of neopatrimonialism lies in the politics of belonging, in which the kinship affiliation is very strong and people always want to identify with where they come from. The abuse of this by political elites becomes an extreme manifestation of neopatrimonialism. This can be evidenced from the cases of 'indigene and stranger', 'insider and outsider' politics and, of course, ethnic favouritism (ibid.).

There is an expanding body of literature examining the multifaceted role higher education plays in conflict-affected contexts. This literature includes the highly politicised process of higher education reform in Kosovo (Bache and Taylor 2003), the contested role of higher education in statebuilding and peacebuilding in Afghanistan (Sahar and Kaunert 2020), donor-government contest over higher education in post-war Rwanda (Hayman 2004), higher education reform during conflict in Sudan (Babyesiza 2012), and higher education's complex role in mediating identity and conflict in the Balkans (Bacevic 2014). This body of literature, by engaging the dynamic processes of the securitisation of higher education by the national governments or elites, indicates that in contexts undermined by national or regional turbulence, higher education can be 'securitised' and 'politicised' through a range 
of discursive and non-discursive acts. In the current context of Afghanistan, this article focusses on three features that are inherent to higher education and constitute the prominent components of threat construction by the state elites. These features are (a) higher education as a platform to forge political networks/organisations; (b) academic training; and (c) socialisation into ideals of social justice. Although, these features have not been studied through the securitisation framework in the context of Afghanistan, research alluded to above has, however, demonstrated how these features in similar post-conflict contexts can acquire contentious characteristics, leading to securitisation and desecuritisation moves.

The higher education sector in Afghanistan has played a critical role in providing student and academic bodies platforms to build political networks or organisations to demand change and challenge the status quo. Institutions of higher education in Afghanistan have trained students to critically engage with their surroundings and challenge the ideas and values that influence their conditions and social status within a given human ecology (Sahar and Kaunert 2020). Additionally, the state failure to build an ineffective system of governance and the hierarchical system and pedagogical processes that ruled the universities, instead of promoting critical teaching and learning settings, have provided conducive grounds for ideo-political political agents (communists and Islamists) who came to shape and drive the nation's trajectory for decades (Emadi 2001), with significant spill-over implications for the current reconstruction efforts. It is currently argued that Afghanistan's prestigious centre of higher education (Kabul University) continues to be an institution where intellectual leaders cut their political teeth (Graham-Harrison 2013). It becomes more relevant when put into context as the University was particularly influential in the 1950s-1970s, when it nurtured two conflicting ideological and political categories of men, where the first category (the Communists) would go on to topple the republic through a military coup and facilitate the Soviet invasion of Afghanistan, and the second category (the Islamists) would lead the anti-Soviet resistance and then drag the country into civil war in the 1990s (Ibid.).

Academic training is a prominent feature of higher education in conflict-affected contexts, where it plays critical roles in reconstruction processes through teaching or training (Altbach 2009). Academic programmes in several key subjects are pivotal in supplying the required skills in a range of areas at the core of rebuilding war-torn societies (Ibid.). Educational programmes, in addition to generating human force to drive reconstruction endeavours, can also help communities to build resilience, determination, and perseverance to cope with and challenge the structures that produce and perpetuate prejudice (Davies 2013). For instance, specialists in the disciplines of engineering, law, urban planning, education, and architecture can populate these fields, where they can utilise their positions and agency to influence the built environment, schools, and the legal system. It has been more argued more compellingly that in post-war contexts 'without higher education geared towards producing responsible citizenship and marketable skills in the economy, neither administrative reform nor competitiveness can be realistic goals (Ghani et al. 2005).' Another feature of higher education that is the unit of analysis in this article is its capability to socialise its subjects into the ideals of social justice and equality. Higher education nurtures 'values such as institutional autonomy, academic freedom, equitable access, social responsibility, and accountability, which embed deeper meanings than the relatively light frame (e.g., peace or justice) (Sahar and Kaunert 2020).' These values are suggested to 'include equality of opportunity, human rights, rationality, intellectual freedom, tolerance, solidarity, independence and coexistence, cooperation, consultation, inclusion, understanding of and respect for others and the environment, and accountability for decisions and responsibility for actions (Gardia and Mehta 2014).' Research has shown that higher education 'helps its subject to move beyond conceptual understanding to learning experiences and develop these core competencies to nurture participatory skills and civic dispositions for exercising the rights and carrying out the responsibilities and duties of citizenship in a democracy (Ibid.).' Higher education, therefore, provides a platform for the 
socialisation of individuals or groups into certain norms and practices that advance social justice and challenge the prejudice premised on ethnic, religious, and cultural differences.

\section{Methodology}

This research article is built upon a hypothetico-deductive research strategy, developed by Karl Popper (Popper 2002), which encourages a structured approach to data collection and analysis. The methodology of this project is based on the principle of methodological triangulation between the relevant secondary literature, official documents and governmental reports, and participatory action research (PAR), as outlined below. PAR is a research method, wherein 'researchers and social actors join forces in collective research and analysis [with] social actors contribut[ing] their knowledge of the issues ... [while] researchers help to systematize this knowledge ... and [lead] the collective analysis exercise (Stiefel 2001).' This joint collaboration helps generate inclusive data and develop an effective data analysis framework, reflecting reality in its 'real' form and share insights and knowledge that would not otherwise be available (Rasheed and Munoz 2016). Moreover, this spirit of collaboration is echoed in the choice to prioritise data generation (Ibid.), where 'the researcher is often regarded as a co-producer of the data, which are produced as a result of an interaction between researcher and [research participants]' (Bridget 2004, p. 181).

In designing our qualitative study, we used a 'purposeful selection' method. It is '[a] strategy [where] particular settings, person, or activities are selected deliberately to provide information that is particularly relevant to ... questions and goals (Maxwell 2013, p. 98).' During our research, purposeful selection enabled us to recruit a relatively representative perspective of individuals who are active in the higher education sector. Data were collected through qualitative semi-structured interviews with senior officials from the Afghan Ministry of Higher Education (MOHE), senior academics and officials from Kabul University and two private universities in Kabul, and two civil society activists. These participants were selected for their influential roles in policymaking, appearance in media, and teaching activities, which are further supported by their privilege, power, skills in the society, and influence over their audience. These interviews helped us gain insights into the mechanisms by which higher education is being securitised for its potential in contributing to or mitigating security threats such as the promotion of radicalisation within Afghanistan's broader turbulent complex political and security situations. The data were collected in the summer of 2018 in Kabul, followed by follow-up discussions through Skype and mobile phone over an extended period of 12 months (December 2018-December 2019). The data were recorded into Persian/Farsi language. However, it would have been helpful to collect data in the Pashto language too. However, the author's lack of competence in the Pashto language as well as the widespread use of the Persian/Farsi language by the participants counteracted this limitation. Data were thematically analysed using the conflict analysis framework (Department for International Development (DFID), "Conducting conflict assessments: guidance notes") to discuss security, political, economic, and social dimensions of the securitisation activities in Afghanistan and the role of higher education in this process. The next section presents the research's key findings and analysis narrated through intensive fieldwork conducted in Afghanistan.

\section{Securitising Practices in Higher Education in Afghanistan: An Empirical Analysis}

Whilst there remains a caveat that the article mentions, the Afghan Ministry of Higher Education briefly - in limited instances - and, given the societal and political fragmentation Afghanistan experiences and the size of Afghan higher education sector, provides concrete proof that elites securitising of higher education remains a daunting task. Relatedly, delineating the question of how the state elites securitise higher education from the elites practices of excluding certain groups due to ethnic or economic interests equally requires a good deal of substance and analysis. However, in this section, the article attempts to redress these caveats by providing specific practices or examples of securitisation of the 
higher education sector by the state elites and discussing who (which/what group of elites) engages in which strategies and concrete actions to influence certain aspects of higher education. The data indicate that the securitisation of higher education in Afghanistan by state elites takes place through certain specific tools and practices which are not necessarily discursive and explicit in content and practice. The most prominent practices include mainly (1) the obstruction of the formation of critical ideas and politics; (2) the obstruction of economic opportunities; and (3) the obstruction of social justice. The remainder of this section discusses these practices and the specific tools through which these practices are executed in a thematic manner.

\subsection{Obstruction of the Formation of Critical Ideas and Politics}

Afghanistan provides a fertile 'context' that is as equal to a successful securitisation and desecuritisation move as actors and audience, owing to the age-old roots of political tensions, exacerbated by state integration (1978) and the pursuant civil war (1979-2001). The international intervention in 2001, aimed at resurrecting the country and addressing the overdue popular frustration, appears to fail (Suhrke 2013). The context formulation, drawing on Buzan et al. (1998), may take two forms in Afghanistan; it is synonymous with sectors (military, political, etc.) on the one hand, and it refers to 'conditions historically associated with the threat', on the other hand, as the 'local political histories' (Bubandt 2005) of communities are decisive in consolidating how securitisation operates in a given context. Similarly, a contextual analysis offers a 'vernacular' understanding of security practices, and the way in which security is understood, locally, is a crucial factor for uncovering the concrete practices of security (Wilkinson 2011).

In post-2001 Afghanistan, there is incremental concern over the growing prominence of ethnic politics in elites and mass behaviours and practices including elections (Sahar and Sahar 2019), leading to an emerging discourse on processes in which an equitable higher education is viewed by various elite pacts as a threat to their interests. The securitisation discourse within the higher education sector is the direct outcome of the securitisation moves carried out by elites within the state structures and is executed by a range of actorsmost prominently by academics, service personnel, students, and individuals or groups associated with the sector. This relationship between the securitising actors and these groups or individuals with a symbiotic identity (e.g., simultaneously being the audience as well as the executive agent) often leads to a cacophony of contentious rhetoric that appears to be so dominant that it can define and drive the national discourses about the broader ideas of national identity and cohesion.

The influence of ethnic politics in Afghanistan has increasingly become intertwined with daily activities and practices including the social, political, and cultural. This contextual perspective on security comprises a critical element of securitisation processes as the semantic repertoire of security is a combination of textual meaning-knowledge of the concept acquired through language (written or spoken)-and cultural meaning-knowledge historically gained through previous interactions and current situations' (Balzacq 2011, p. 11). In conflict-affected contexts, legacies of prior conflict whether ethnic, religious, economic, or social have significant repercussions for peace durability, if not adequately addressed. Conflict propensity is higher in countries that have experienced insurgencies or civil wars (Kaufmann 1996). Precisely, the same factors such as economic crisis, social animosity, or religious tensions that facilitated the outbreak of a conflict can facilitate conflict recurrence (Ibid.). The fear associated with the legacies of the civil war in Afghanistan (1978-2001), as was depicted by a lecturer at Kabul University, significantly informed the politics of statebuilding and power control in the post-2001 contexts:

Look, the civil wars broke the cycle of power and wealth distribution. The historical monopoly of the Pashtun elites over the state was seriously undermined. So, the Pashtun leaders and elites understood and interpreted it as their deslinination ... ${ }^{1}$

The same participant went on to reflect how the state elites sought to reverse the process and revise their control over state power and resources and how the state elites 
viewed the progress and participation of other ethnic groups a security threat to their monopoly over the state configurations in the future:

The people who have controlled the state for ages, view the state their inherited property. These people don't simply want other ethnic and social groups to grow powerful and claim their rights in the state. An inclusion of more ethnic groups in the political structures and institutions can pose a threat to a centralised control of state. This is what happened in the aftermath of the civil wars and has a potential to repeat itself. ${ }^{2}$

When a society undergoes war, it generates different layers of social animosities, fears, and hatreds that are important to effectively manage in the post-conflict era to mitigate the recurrence of violence (Kaufmann 1996). Legacies of previous wars result in mutual hatreds or animosities that occupy populations socially and psychologically, significantly increasing the likelihood of conflicting parties to resort to fresh violence (Kaufmann 1996). Relatedly, material and organisational legacies can function as powerful impetus for renewed violence. The 'organizational legacies of prior conflicts-the ties that former combatants form with one another, with agents who can deliver the necessary resources for rebellion, and so on-make post-conflict states particularly vulnerable' to foster an environment that breeds violence. Organisational legacies tie together the same social networks that fight in wars, providing the organisational and social prerequisites for the re-emergence or formation of armed groups in post-conflict settings (Christensen and Utas 2008).

The fear and legacies of the civil wars in Afghanistan that were informed by increasing ethnic consciousness and fought primarily along ethnic lines, influence the elite perspective and political behaviours through laws and policies such as the practices of the securitisation of higher education in attempts to undermine certain ethnic and social groups to form critical ideas and politics that would challenge the monopolised control and governance of the state structures. The participants reported that the securitisation practices or perspectives that viewed an equal access to higher education by all ethnic groups as a security threat to the state contradicted the values-based features of higher education and undermined its role in promoting social justice, ${ }^{3}$ critical ideas and politics, ${ }^{4}$ and empowering individuals and communities through equitable provisions of economic opportunities. ${ }^{5}$ Reflecting on the wider dynamics and processes of the securitisation practices within the sector, a former senior advisor to the Afghan Ministry of Higher Education stated that policymakers within the sector and their likeminded peers in other state institutions feared access to higher education by certain groups as a security threat to their perpetual monopoly over the state power and resources and sought to undermine these groups' political aspirations and organisational ability to forge political platforms. Depicting his observations of the means and instruments of the securitisation of the sector, he stated that the state elites adopted systemic and cross-organisational practices, involving a fertile context, varied and apt actors, and receptive audience:

Ministers, deputy ministers, and senior officials work together like a chain to limit or slow down the progress of some ethnic groups like the Hazaras and Uzbeks. These actors view these ethnic groups when empowered a security threat to their monopoly on power and resources. These actors are spread across different formal and informal institutions and pursue a common agenda. ${ }^{6}$

He went on to lament:

At the MOHE, many people from other places interfered with policies and tried to develop them in a way that better served their ethno-nationalist agenda. These policies or the politics behind them are not discussed publicly. They are developed and implemented in a more hidden manner. ${ }^{7}$

Regarding the role higher education could play in changing political discourses and practices by empowering more segments of the populations, some academic and administrative staff at Kabul University viewed the University as a critical plateau where people could develop political perspectives and ideas and forge a platform to outreach 
to the wider public to mobilise them around their agenda. ${ }^{8}$ However, these participants stated that the state elites deliberately undermined the University to facilitate healthy discourses that could influence the national politics in a more constructive way. ${ }^{9}$ The politicisation of Kabul University for specific ideological and political purposes by the state elites was a prominent theme that emerged from the analysis. The majority of participants viewed that the University failed to deliver its key objectives (e.g., equitable access, quality, and critical education) mainly due to the politicisation of the University through certain practices, including marginalisation of certain ethnic groups from senior appointments, allocation of budget, or curriculum development that are informed by political objectives. 10 Additionally, some participants at Kabul University and at the Afghan MOHE were of the view that the security threat (real or perceived) constructed and advanced-albeit non-discursively - by the elites through educational infrastructures seriously undermined their ability to forge relationships with academics, student bodies, and the broader society to pursue a politics that is premised on the ideas of equality and modernity. A senior academic at Kabul university shared his experience:

I have been teaching at Kabul University for over 20 years now. My colleagues and I tried many times to organise a political front. We wanted to pursue a more progressive political agenda. But all of our efforts failed. Many people from different organisations who fear such politics derailed our plans. These people interfered with our activities. They used different strategies like demotivating some of our colleagues or even blackmailing us. ${ }^{11}$

Similarly, another senior academic at Kabul University highlighted the varied ways the state elites adopted to limit the political and intellectual activities they perceive as a threat to the centralisation of power and resources. He lamented:

Once we planned to establish a quarterly at Kabul University. The then VC asked us to work under the direction of his team. He said that our agenda was too political. We refused. We knew the VC and his people wanted to achieve two things. Firstly, they wanted to use us as a means to increase their reach to a wider audience. Secondly, they wanted to control our freedom and ability to challenge the current conditions that we denounce. ${ }^{12}$

Subversion of critical actors and voices across the higher education sector in general, and at Kabul University in particular, emerged as one of major tools utilised to securitise the University and its provisions. The University was viewed by the participants to have been securitised for its capability to breed critical thinking, which would challenge the social construct of history, identity, and power structures that have traditionally served the more powerful ethnic groups and the state elites. Additionally, critical thinking can function as a means and ability to judge well, enables its subject to scrutinise the logic of its surroundings, enables its subject to form sound beliefs, enables it subject to interpret the social and historical events with curiosity, and provides a determined motif for reasonable change. ${ }^{13}$ Since there is an inherent politicisation to identifying something as a security problem, the elites in Afghanistan (e.g., academics, policymakers, academic/students union, etc.), often try to use higher education institutions and provisions as the instrument of securitisation to continue or extend their influence over the sector. Securitising an issue serves certain aims and 'ultimately enables certain elites to increase their power as a consequence of being granted special privileges in dealing with a security issue or, in other words, breaking free from the procedures and rules that actors 'would otherwise be bound by (Buzan et al. 1998, p. 25).' A freelance academic put it into perspective vividly:

The elites in Afghanistan manipulate educational processes to expose their audience to some single model of activism or recruitment and socialise them with commitment premised on social or structural psychological variables deliberately designed and delivered to correspond to specific conditions. ${ }^{14}$

These conditions, once crystallised, provide the elites the legitimacy needed to successfully securitise an issue and deepen their monopoly over power. ${ }^{15}$ Educational activities 
can provide a foundation for a systematic development and socially constructed conscience amongst the audience, who would ultimately be drawn into the discourses and practices advanced by the securitising actors. The development of a common agenda between the securitising actors and the audience provides a platform which can shape the power configurations that 'speaker and listener bring to the interaction' (Balzacq 2005), and might fortify the securitisation agenda.

The failure of the new political context in Afghanistan to restructure the state based on a more pluralistic foundation and interpretations of the national history is disenfranchising a large number of students, members of staff, and the public. It appears that whilst most Afghans strive for a more inclusive polity that defies conflict-hardening structures, this aspiration is being denied out of political and economic incentives. This deprivation of opportunity leads to a significant reduction in student and academic bodies' ability to organise themselves along a particular ideological or political perspective that might help them realise their human potential and political objectives, such as a more inclusive political or economic participation.

\subsection{Obstruction of Economic Opportunities}

The economic prospects of higher education in the fragile context of Afghanistan, that risks relapse into violence, can either support or frustrate the post-war recovery process. If the sector is unable to respond to the economic complexities of post-war requirements and a significant youth bulge (Urdal 2006), it might produce graduates with skills and knowledge irrelevant to economic needs and high graduate unemployment (Milton and Barakat 2016, p. 406), which can provide resources for conflict, criminal activity, and violence. In Afghanistan's transition to privatised and liberalised economies, higher education is viewed to have been continued from a previous era of the command economy and is slow to adapt to market demands (Harb 2008), leading to a loss of confidence in education and resorting of a large chunk of youth to alternative opportunities, which may well include recruitment to armed groups and conflict. However, despite this frustration, higher education proffers the capability to develop the agency of its subjects, define their place during instability and challenge the socially constructed security threats promoted by a range of actors through discourses and practices, often manifested in prejudice and hatred act of speech. A senior official at Kabul University made a detailed argument:

Higher education in Afghanistan has laid a foundation for a more inclusive economy. It may not be perfect but still something ... a large number of people with higher education, are earning good salaries. I know, there are lots of problems, but higher education has helped people to improve their social status. ${ }^{16}$

This same participant continued:

Whilst access to higher education my not be always fair, it certainly softens the walls that discriminate against some layers of the society. This is why the monopolist state actors obstruct ethnic groups [where they can] to access higher education and gain the skills needed for the entrance and competition within the evolving economy. ${ }^{17}$

A female academic also at Kabul University appreciated that access to higher education expanded significantly in the post-2001 contexts and benefitted most segments of the Afghan populations, and stated:

The Afghan state and the University elites collaboratively barred some high-flying Hazara students and faculties to be recruited to high-paying positions. ${ }^{18}$

She further elaborated:

One of my own students [Hazara] achieved really high marks in all her exams but was denied a teaching post ... Later, I heard that the faculty director had said it was not wise to give money to someone who would later come and challenge us. ${ }^{19}$

This micro or local understanding and construction of security manifested in local experiences, fears, and anxiety constitute the vernacular securities of the securitised indi- 
vidual or collectives. The securitising actors by securitising certain groups infuse in their subjects a sense of everyday insecurity by persistently viewing particular populations a security threat by virtue of their identity or sociopolitical position (Jarvis 2019). Using the notion of vernacular securities for empirical investigation of security politics, Nicole George (George 2017; Huff 2017) explores the confluence of a wide range of norms or values such as religious, customary authority, and state-based in the policing of Fijian gender norms. She highlights that the interconnection of anxieties relating to Christian values, local cultural norms, and social order accounts for the particularly aggressive policing of sex work(ers) that intensified from 2007 onward.

In the context of Afghanistan, this same participant was of the view that the securitisation of higher education instead of equipping its subjects with the skills and knowledge necessary to gain employment opportunities and economic wellbeing, barred its subject to realise their aspirations leading to a perpetual sense of exclusion and uncertainty. She further argued that in a country where poverty was rife and economic stability provided the core to access social privileges, including quality (e.g., private or international education) and building of social and political capital, access to economic opportunities became a scarce commodity, and the actors and institutions who traditionally controlled these opportunities would attempt to protect them from other contenders such as ethnic or social groups. She provided accounts of her personal experience on the practices and tools the state or pro-state elites at Kabul University adopted to construct the security threat they viewed was caused by the economic empowerment of the historically marginalised ethnic or social groups. She lamented:

I have seen many brilliant students and academics who were rejected to be recruited to senior academic or managerial positions. Because these people were either Hazara or Uzbek and so on. The people who are in control of power and economic resources see others as threat to their authority. So, these powerful actors try to deny others access to economic opportunities. Because, one day these powerless people might become powerful and have enough resources to challenge these people's (securitising actors) interests. ${ }^{20}$

\subsection{Obstruction of Social Justice}

In addition to political and economic dimensions of higher education, the sector is perceived as a security threat to the current power structures, owing to the sector's ability to socialise its subjects to norms and practices, which nurture equality and social justice. A society that is premised on justice and national pride proffers the capability to undermine the underlying factors that legitimise the behaviours and actions of the elites, who espouse and advocate for ethno-nationalist agenda. Additionally, this development undermines the power relations between the elites and an audience that now endeavours for equality of rights and responsibilities - thus demonstrating less inclination to identify with or accept the securitisation moves. The extent and dynamism of these power relations is critical 'as they shape distinctive ways of thinking, acting and the subject formation that precedes, accompanies and follows processes of securitization (Balzacq et al. 2016, p. 502).' Education in Afghanistan, whilst offering a logical narrative of a transformative process to build sustainable peace, can equally play a socially destructive role in politicising or weaponising national identities as well as the discourses, concepts, and processes involved in political and social affairs (Pherali and Sahar 2018). In attempts to derail the democratisation processes that would empower the society against corruption and monopolisation of power by certain elite networks, the elites tend to single out vulnerable individuals and, in particular, those who hold more conservative ideas on human rights, women's rights, ethno-religious pluralism, and girls' education as pawns to be manipulated in the cynical politics of extremism and fear. ${ }^{21}$ This approach to preserve the monopoly over power brings two interrelated activities, including securitising moves and 'facilitating condition' enabled by 'specific cultural and historical experience' (Huysmans 1998a) into interaction. In Afghanistan, the securitising actors view social empowerment and social justice as 
a threat to the current political structures and configuration of power, and thus tend to convert it into a fear to gain more relevance and access to state power and resources. ${ }^{22} \mathrm{~A}$ former senior advisor to the Afghan Ministry of Higher Education in Kabul provided a vivid explanation:

The manipulative elites fear justice and equality. They want to keep the country in this mess to protect their own interests. These elites don't allow to update the pedagogy with more modernist contents. They don't allow critical debates or recruit more critical staff. They talk about change in negative sense. The ultimate outcome is a widespread fear and an opportunity for relevant actors to strengthen their positions and influence the national politics. ${ }^{23}$

Similarly, another senior female academic also at Kabul University stated that the officials at the Ministry of Higher Education, who are pro-state and support a heavily centralised system of governance, bar the teaching or discussing certain subjects critically. She explained:

Once, some of my colleagues tried to revise history and social studies subjects in our department. We wanted to facilitate a critical approach to teaching history and culture and etc. The then VC and senior officials from the Ministry of Higher Education threatened us and told us that we might get sacked ... ${ }^{24}$

This section discussed the instruments and tools the elites in Afghanistan adopt to manipulate educational spaces to preserve the current condition that allows certain groups or networks to yield relative leverage to other ethnic or social groups. In this process, the elites seek to undermine higher education's ability to help its subjects to develop political perspectives, networks, and platforms to outreach to the wider public that is frustrated by the current political arrangements. Education can function as a powerful instrument to promote cultural diversity and generate a shared identity with which different individuals and groups can identify and learn and practice ideological and political messages, including social cohesion, ethno-religious tolerance, and inertcommunal interactions. With access to such platforms, individuals are able to find others who share their feelings and, as such, develop a collective consciousness that is sensitive to certain political, social, and religious issues (Javanbakht 2019). According to neuroscience research, this ability to find a community that shares one's feelings bears significant importance for group solidarity as it provides a sense of security and validates ones fears and feelings of hate (Daniels 2018). Hence, higher education in the current context of Afghanistan is being securitised by the elites through persistent and systematic practices of marginalisation of certain ethnic or social groups to undermine their aspirations for social and political transformations out of fear or a threat and/or threatening image to the centralised command of power. As such, higher education is rather manipulated to promote norms and practices that underpin the antagonistic local patterns of politics and competing ideals and sociocultural incompatibility. This state of contention, informed by 'a cultural-historical interpretation of the rhetorical structure [of securitization]' of Afghanistan (Huysmans 1998b, p. 501), to borrow from Huysmans, builds a pathway for the securitising actors to insert security threats-perceived or real-into collective imagination and successfully mobilise the referent object of security for their interests.

These securitisation practices of higher education in Afghanistan, often carried out through non-discursive and implicit moves, can be viewed as practices that are defined as 'a routinised type of behaviour which consists of several elements, interconnected to one another: forms of bodily activities, forms of mental activities, 'things' and their use, a background knowledge in the form of understanding and know-how, states of emotion and motivational knowledge (Reckwitz 2002, p. 249).' Similarly, Balzacq et al. (2010) state that securitisation moves can take hold any moment in respond to a particular event and, thus, for analysing security practices, (in)securitisation is not necessarily the result of a rational design wherein goals are set beforehand, following a predetermined agenda. Looking at securitisation as a social process, Pouliot following Bourdieu argues that 'social 
action is not necessarily preceded by a premeditated design. A practice can be oriented toward a goal without being consciously informed by it (Vincint 2008, p. 261).' As such, 'securitization consists of practices which instantiate intersubjective understandings and which are framed by the habitus inherited from different social fields (Balzacq et al. 2010, p. 3).' In a non-Western context, it is suggested that the securitisation theory's Eurocentric assumptions about the social and political context, in which any securitisation occurs together with the issue of privileging of speech over other means of expression, expose its restrictive formulation (Wilkinson 2007). In the non-democracy and non-Western contexts, for conceptualising securitisation effectively, it is important to consider and account for the informal dynamics in which securitisation occurs without fulfilling the prerequisites set by the Copenhagen School, as is in the case of Afghanistan, where different state elites confluence in both formal and informal structures and develop policies that, in their perspective, reduce the security threat to their interest. In similar contexts such as Kyrgyzstan, it is argued that during the sociopolitical turmoil that toppled President Askar Akayev in March 2005, 'the relationship between speech and action is more complex than the portrayal offered by securitization. Particularly in the case of domestic politics, action may precede the speech-act that is fundamental to securitization' (Wilkinson 2007, p. 22). In the case of Afghanistan, the securitization practices adopted by the state elites and the subsequent local experiences and anxieties manifested in the participants' vocabulary and speech may help make the case that 'sufficient action' may replace or supplement the speech-act as the driving logic in the process of securitization' (Wilkinson 2007, p. 23).

\section{Conclusions}

This article has examined the securitisation processes and practices of higher education in post-2001 Afghanistan. The article highlights that the higher education, in a context where communities all faced a collective 'security' threat, might function as a securitisation vehicle. The social construction of human interactions and community cohesion is significantly influenced by social norms, whereby actors are socialised into new norms, perceptions of interest, and values. Norms, practices, and processes of higher education can influence and shape the psychosocial constructs and the intimate feelings of their audience. They are shaped by the audience through a range of discourses and institutions. Since the emergence and normalisation of norms and practices and, by default, securitising norms and practices, involves complex processes, institutions, rules, and shared practices that concern individual and collective lives, education plays a significant role in institutionalising these ideas that ultimately influence audience behaviour and audience interests. Particularly, education becomes crucial in fragile contexts by becoming an inseparable and a co-constitutive part of stabilisation and peacebuilding processes. Yet, education is also a multifaceted process. Education facilitates the perpetuation of hegemony and segregated and unjust societies through the manipulation of history and suppression of minority languages and cultures. Hence, in the context of post-2001 Afghanistan, higher education sits at a critical juncture to either play a constructive or a destructive role in institutionalising the securitisation and politicisation of norms and practices. In the current fragile context of Afghanistan, it is relatively simple for the securitising actors to construct threats, which necessitate security solutions. It is within pre-existing social discourses that enemies are constructed and dehumanising processes are accomplished that ultimately radicalise society.

Author Contributions: Writing—original draft, C.K. and A.S. Both authors have read and agreed to the published version of the manuscript.

Funding: This research was funded by Erasmus plus funding under the Jean Monnet programme (Module, Chair, Centre, and Network).

Conflicts of Interest: The authors declare no conflict of interests. 


\section{Notes}

1 Interview with a lecturer at Kabul University through mobile phone, Sheffield/Kabul, 28 September 2018.

2 Interview with a lecturer at Kabul University through mobile phone, Sheffield/Kabul, 28 September 2018.

3 Interview with a lecturer at Kabul University through mobile phone, Sheffield/Kabul, 28 September 2018.

4 Interview with a VC at a private university through mobile, Sheffield/Kabul, 19 September 2018

5 Interview with Deputy MOHE, Kabul, 23 August 2018.

6 Interview with former senior advisor to the Afghan MOHE. Kabul. 9 August 2018.

7 Interview with former senior advisor to the Afghan MOHE. Kabul. 9 August 2018.

8 Interview with a professor at Kabul University through mobile phone, Kabul, 10 August 2018.

9 Interview with a lecturer at Shaheed Rabbani University through mobile phone, Kabul, 10 August 2018.

10 Interview with a female lecturer at Kabul University, Kabul, 12 August 2018.

11 Interview with a senior academic at Kabul University, Kabul, 12 August 2018.

12 A senior academic at Kabul University

13 Interview with a lecturer at a private university through Skype, Sheffield/Kabul, 14 August 2018.

14 Interview with a freelance academic through mobile phone, Kabul, 12 August 2018.

15 Interview with a lecturer at a private university through Skype, Sheffield/Kabul, 14 August 2018

16 Interview with a senior official at Kabul University, Kabul, 12 August 2018.

17 Interview with a senior official at Kabul University, Kabul, 12 August 2018.

18 Interview with a female lecturer at Kabul University, Kabul, 12 August 2018.

19 Interview with a female lecturer at Kabul University, Kabul, 12 August 2018.

20 Interview with a female lecturer at Kabul University, Kabul, 12 August 2018.

21 Interview with a freelance academic through mobile phone, Kabul, 12 August 2018. Interview with a female lecturer at Kabul University, Kabul, 12 August 2018.

22 Interview with former senior advisor to the Afghan MOHE. Kabul, 9 August 2018. Interview with a lecturer at a private university through Skype, Sheffield/Kabul, 14 August 2018.

23 Interview with a former senior advisor to the Afghan MOHE. Kabul, 14 August 2018.

24 Interview with a female lecturer at Kabul University, Kabul, 12 August 2018.

\section{References}

Altbach, Philip G. 2009. Peripheries and Centers: Research Universities in Developing Countries. Asian Pacific Education Review 10: 15-27. [CrossRef]

Arshad-Ayaz, A., and M. A. Naseem. 2017. Creating “Invited" spaces for counterradicalization and counter-extremism education. Diaspora, Indigenous and Minority Education 11: 6-16. [CrossRef]

Babyesiza, Akiiki. 2012. Higher Education Reform During and After Armed Conflict: The Case of Sudan. In Effects of Higher Education Reforms: Change Dynamics. Edited by Martina Vukasovic. Rotterdam: Sense, pp. 121-35.

Bacevic, Jana. 2014. From Class to Identity: The Politics of Education Reform in Former Yugoslavia. Budapest: Central European University Press.

Bache, Ian, and Andrew Taylor. 2003. The Politics of Policy Resistance: Reconstructing Higher Education in Kosovo. Journal of Public Policy 23: 279-300. [CrossRef]

Balzacq, Thierry. 2005. The Three Faces of Securitization: Political Agency, Audience and Context. European Journal of International Relations 11: 171-201. [CrossRef]

Balzacq, Thierry. 2011. A Theory of Securitization: Origins, Core Assumptions, and Variants. In Securitization Theory: How Security Problems Emerge and Dissolve. Edited by Thierry Balzacq. London: Routledge, p. 11.

Balzacq, Thierry, Sarah Leonard, and Jan Ruzicka. 2016. Securitisation Revised: Theory and cases. International relations 30: 494-531. [CrossRef]

Balzacq, Thierry, Tugba Basaran, Didier Bigo, Emmanuel-Pierre Guittet, and Christian Olsson. 2010. Security Practices. International Studies Encyclopedia Online. Edited by Robert A. Denemark. Available online: http://www.open.ac.uk/researchprojects/iccm/ files/iccm/olsson-christian-publication7.pdf (accessed on 30 November 2020).

Barfield, Thomas. 2011. Afghanistan's Ethnic Puzzle. Foreign Affairs 90: 55-58.

Bigo, Didier. 2001. Migration and Security. In Controlling a New Migration World. Edited by Virginie Guiraudon and Christian Joppke. London: Routledge.

Bigo, Didier. 2006. Internal and External Aspects of Security. European Security 15: 385-404. [CrossRef]

Bingo, Didier. 2002. Security and Immigration: Toward a Critique of the Governmentality of Unease. Alternatives: Global, Local, Political 27: 63-92.

Bridget, Byrne B. 2004. Seale, Clive, Editor. Researching Society and Culture. London: SAGE Publications.

Bubandt, Nils. 2005. Vernacular Security: The Politics of Feeling Safe in Global, National and Local Worlds. Security Dialogue 36: 275-96. [CrossRef] 
Buzan, Barry, Ole Wæver, and Jaap de Wilde. 1998. Security: A New Framework for Analysis. London: Lynne Rienner.

Carol, Riphenburg. 2005. Ethnicity and Civil Society in Contemporary Afghanistan. Middle East Journal 59: 31-51.

Christensen, Maya M., and Mats Utas. 2008. Mercenaries of Democracy: The 'Politricks' of Remobilized Combatants in the 2007 General Elections, Sierra Leone. African Affairs 107: 515-39. Available online: https://academic.oup.com/afraf/article/107/429/ $515 / 79954$ ?login=true (accessed on 30 November 2020). [CrossRef]

Ciută, Felix. 2010. Conceptual Notes on Energy Security: Total or Banal Security? Security Dialogue 41: 123-44. [CrossRef]

Corry, Olaf. 2012. Securitisation and "Riskification": Second-Order Security and the Politics of Climate Change. Millennium: Journal of International Studies 40: 246-49. [CrossRef]

Croft, Stuart, and Nick Vaughan-Williams. 2016. Fit for Purpose? Fitting Ontological Security Studies 'into' the Discipline of International Relations: Towards a Vernacular Turn? Cooperation and Conflict 52: 12-30. [CrossRef]

Daniels, Jessie. 2018. The Algorithmic Rise of the “Alt-Right". Available online: https://journals.sagepub.com/doi/10.1177/15365042 18766547 (accessed on 30 November 2020).

Davies, Lynn. 2013. Education, Change and Peacebuilding. Bonn: Working Group on Peace and Development (FriEnt).

Durodie, B. 2016. Securitising education to prevent terrorism or losing direction. British Journal of Educational Studies 64: 21-35. [CrossRef]

Durrani, Naureen, and Máiréad Dunne. 2010. Curriculum and national identity: exploring the links between religion and nation in Pakistan. Journal of Curriculum Studies 42: 215-40. [CrossRef]

Emadi, Hafizullah. 2001. Radical Political Movements in Afghanistan and Their Politics of Peoples' Empowerment and Liberation. Central Asian Survey 20: 427-50. [CrossRef]

Ezeokafor, Edwin, and Christian Kaunert. 2018. Securitization outside of the West: conceptualizing the securitization-neopatrimonialism nexus in Africa. Global Discourse 8: 83-99. [CrossRef]

Fisher, Jonathan, and David Anderson. 2015. Authoritarianism and the securitization of development in Africa. International Affairs 91: 131-51. [CrossRef]

Gardia, Alok, and Deepa Mehta. 2014. Rethinking Teacher Effectiveness in Democratic Citizenship Education for Ensuring Peace. In Citizenship, Democracy and Higher Education in Europe, Canada and the USA. Edited by Jason Laker, Concepción Naval and Kornelija Mrnjaus. New York: Palgrave Macmillan, pp. 86-107.

Gearon, L. 2012. European religious education and European civil religion. British Journal of Educational Studies 60: 151-69. [CrossRef]

George, Nicole. 2017. Policing 'Conjugal Order': Gender, Hybridity and Vernacular Security in Fiji. International Feminist Journal of Politics 19: 55-70. [CrossRef]

Ghani, Ashraf, Clare Lockhart, and Michael Carnahan. 2005. Closing the Sovereignty Gap: An Approach to Statebuilding. London: Overseas Development Institute.

Graham-Harrison, Emma. 2013. Kabul University spawns next generation of freedom fighters. The Guardian, May 27, 1-2.

Greenwood, Maja Touzari. 2013. Copenhagen-Cairo on a roundtrip: A security theory meets the revolution. Security Dialogue 44: 485-506. [CrossRef]

Hampshire, James, and Shamit Saggar. 2006. Migration, Integration, and Security in the UK since July 7. Migration Information Source. Available online: http:/ / www.migrationinformation.org/Feature/print.cfm?ID=383 (accessed on 30 November 2020).

Harb, Imad. 2008. Higher Education and the Future of Iraq. Special Report. Washington, DC: USIP.

Hayman, Rachel. 2004. Are the MDGs Enough? Donor Perspectives and Recipient Visions of Education and Poverty Reduction in Rwanda. International Journal of Educational Development 27: 371-82. [CrossRef]

Howell, Alison, and Melanie Richter-Montpetit. 2020. Is securitization theory racist? Civilizationism, methodological whiteness, and antiblack thought in the Copenhagen School. Security Dialogue 51: 3-22. [CrossRef]

Huff, Amber. 2017. Black Sands, Green Plans and Vernacular (In)Securities in the Contested Margins of South-Western Madagascar. Peacebuilding 5: 153-69. [CrossRef]

Huysmans, Jef. 1998a. The Question of the Limit: Desecuritisation and the Aesthetics of Horror in Political Realism. Millennium: Journal of International Studies 27: 569-89. [CrossRef]

Huysmans, Jeff. 1998b. Revisiting Copenhagen: Or, On the Creative Development of a Security Agenda in Europe. European Journal of International Relations 4: 479-505. [CrossRef]

Ide, Tobias, Adrien Detges, and Timo Leimeister. 2019. Securitisation through the schoolbook? On facilitating conditions for and audience dispositions towards the securitisation of climate change. Journal of International Relations and Development 22: 532-59. [CrossRef]

Jackson, Robert. 2015. The Politicisation and Securitisation of Religious Education? A Rejoinder. British Journal of Educational Studies 63: 345-66. [CrossRef]

Jarvis, Lee. 2019. Toward a Vernacular Security Studies: Origins, Interlocutors, Contributions, and Challenges. International Studies Review 21: 107-26. [CrossRef]

Javanbakht, Arash. 2019. The politics of fear: How it manipulates us to tribalism. The Conversation 1.

Karyotis, Georgios, and Stratos Patrikios. 2010. Religion, Securitization and Anti-Immigration Attitudes: The Case of Greece. Journal of Peace Research 47: 43-57. [CrossRef]

Kaufmann, Chaim. 1996. Intervention in ethnic and ideological civil wars: Why one can be done and the other can't. Security Studies 6: 62-101. [CrossRef] 
Lazaridis, Gabriella. 2011. Introduction. In Security, Insecurity and Migration in Europe. Edited by Gabriella Lazaridis. Farnham Surrey: Ashgate, p. 2.

Léonard, Sarah. 2010. EU Border Security and Migration into the European Union: FRONTEX and Securitization through Practices. European Security 19: 231-54. [CrossRef]

Léonard, Sarah, and Christian Kaunert. 2010. Reconceptualizing the audience in securitization theory. In Understanding Securitisation Theory: How Security Problems Emerge and Dissolve. Edited by Thierry Balzacq. London: Routledge, pp. 57-77.

Léonard, Sarah, and Christian Kaunert. 2019. Refugees, Security and the European Union. London: Routledge.

Luckham, Robin. 2017. Whose Violence, Whose Security? Can Violence Reduction and Security Work for Poor, Excluded and Vulnerable People? Peacebuilding 5: 99-117. [CrossRef]

Maxwell, Joseph. 2013. Qualitative Research Design: An Interactive Approach, 3rd ed. Los Angeles: Sage Publications.

McSweeney, Bill. 1996. Identity and Security: Buzan and the Copenhagen School. Review of International Studies 22: 81-93. [CrossRef]

Messina, Anthony M. 2014. Securitizing Immigration in the Age of Terror. World Politics 66: 530-59. [CrossRef]

Milton, Simson, and Sultan Barakat. 2016. Higher education as the catalyst of recovery in conflict-affected societies. Globalisation, Societies and Education 14: 403-21. [CrossRef]

Pherali, Tejendra, and Arif Sahar. 2018. Learning in the chaos: A political economy analysis of education in Afghanistan. Research in Comparative E International Education 13: 239-58.

Pleasants, Nigel. 1999. Wittgenstein and the Idea of Critical Theory. London: Routledge.

Popper, Karl. 2002. The Logic of Scientific Discovery. London: Routledge.

Porat, Dan A. 2004. It's Not Written Here, But This Is What Happened: Students' Cultural Comprehension of Textbook Narratives on the Israeli-Arab Conflict. American Educational Research Journal Winter 41: 963-96. [CrossRef]

Rasheed, Rebeen A., and Alexander Munoz. 2016. Higher Education and Peacebuilding-A Bridge Between Communities? Journal of Peace Education 13: 172-85. [CrossRef]

Reckwitz, A. 2002. Toward a Theory of Social Practices: A Development in Culturalist Theorizing. European Journal of Social Theory 5: 243-63. [CrossRef]

Sahar, Arif. 2014. Ethnicizing Masses in Post-Bonn Afghanistan: The Case of the 2004 and 2009 Presidential Elections. Asian Journal of Political Science 22: 289-314. [CrossRef]

Sahar, Arif, and Aqila Sahar. 2015. Press and Ethnic Polarization in Post-2001 Afghanistan: The 2014 Presidential Election Experience. Central Asian Survey 35: 105-20. [CrossRef]

Sahar, Arif, and Aqila Sahar. 2019. Ethnic Politics and Political Violence in Post-2001 Afghanistan: The 2014 Presidential Election. Terrorism and Political Violence, 1-22. [CrossRef]

Sahar, Arif, and Christian Kaunert. 2020. Higher education as a catalyst of peacebuilding in violence and conflict-affected contexts: The case of Afghanistan. Peacebuilding 9: 57-78. [CrossRef]

Schetter, Conrad. 2004. Ethnicity and the Political Reconstruction of Afghanistan. Working Paper 3. Bonn: Center for Development Studies (ZEF) University of Bonn.

Simonsen, Sven Gunnar. 2004. Ethnicising Afghanistan? Inclusion and Exclusion in Post-Bonn Institution Building. Third World Quarterly 25: 707-29. [CrossRef]

Stiefel, Matthias. 2001. Participatory Action Research as a Tool for Peacebuilding: The WSP experience. In Peacebuilding: A Field Guide. Edited by luc Reychler and Thania Paffenholz. Boulder: lynne Rienner.

Suhrke, Astri. 2013. Statebuilding in Afghanistan: A Contradictory Engagement. Central Asian Survey 32: 271-86. [CrossRef]

Trombetta, Maria Julia. 2014. Linking climate-induced migration and security within the EU: insights from the securitization debate. Critical Studies on Security 2: 131-47. [CrossRef]

Urdal, Henrik. 2006. A Clash of Generations? Youth Bulges and Political Violence. International Studies Quarterly 50: 607-29. [CrossRef]

Vincint, Pouliot V. 2008. The Logic of Practicality: A Theory of Practice of Security Communities. International Organization 62: 257-88.

Wæver, Ole. 1995. Securitization and Desecuritization. In On Security. Edited by Ronnie D. Lipschutz. New York: Columbia University Press, pp. 46-86.

Wilkinson, Claire. 2007. The Copenhagen School on Tour in Kyrgyzstan: Is Securitization Theory Useable outside Europe. Security Dialogue 38: 5-25. [CrossRef]

Wilkinson, Claire. 2011. The Limits of Spoken Words: From Meta-Narratives to Experiences of Security. In Securitization Theory: How Security Problems Emerge and Dissolve. Edited by Thierry Balzacq. London: Routledge, pp. 94-115.

Zembylas, Michalinos. 2020. Affect/Emotion and securitising education: Re-orienting the methodological and theoretical framework for the study of securitisation in education. British Journal of Educational Studies 68: 487-506. [CrossRef] 